\title{
Omvärdering av offentliga religion
}

\author{
- i skuggan af sekulariseringsteorin ${ }^{1}$
}

LINDA WOODHEAD

ENGLISH ABSTRACT: Even in the most 'secular' of western societies it has become clearer in the 21st century that religion plays a role in public life, and cannot simply be described as 'privatised'. But how should this public role be conceived and analysed? This paper presents a framework for such analysis which takes seriously the diverse roles of different kinds of religion in the differentiated spheres of modern societies (education, law, welfare etc.). In other words, it works with a number of variables: What kind of religion? What religious-secular relation? In which social sphere(s)? What kinds of role does religion play? In what relations to class, gender, ethnicity and other bases of inequality? This differentiated model depends upon a critique of existing approaches to public religion (exemplified by Bryan Wilson and José Casanova respectively), and of their underlying assumptions, including a constriction to the national, a conflation of social differentiation and privatisation, and a narrow church-or congregation-focused view of religion. The result is an analytical tool which is better designed to take account of the diverse forms of public religion to be found at local, national and trans-national level in late-modern consumer societies.

SVENSK RESUMÉ: Under det innevarande århundradet har det också i de mest "sekulära" samhällen $i$ Väst blivit allt tydligare att religion spelar en roll $i$ det offentliga livet och att det inte bara kan beskrivas som något "privatiserat". Men hur skall denna offentliga roll förstås och analyseras? Denna artikel presenterar en ram för en sådan analys som tar de olika roller, som olika slags religioner spelar i de moderna samhällenas differentierade sfärer (utbildning, juridik, välfärd osv.), på allvar. Med andra ord, den laborerar med ett antal variabler: Vilken typ av religion? Vilken är relationen mellan det religiösa och det sekulära? Inom vilken/vilka sociala sfär(er)? Vilken typ av roll spelar religon? I vilka relationer till klass, gender, etnicitet och andra utgångspunkter för ojämlikhet?

1 Denne artikel er oversat fra engelsk af Lars Ahlin. 
Denna differentierade modell tager sin utgångspunkt $i$ en kritik av existerande uppfattningar av offentlig religion (ex. Bryan Wilson resp. José Casanova) och de antagelser som de utgår ifrån, inklusive en insnävning till det nationella, en sammansmältning av social differentiering och en snäv kyrko- eller denominations-fokuserad syn på religion. Resultatet är ett analytiskt verktyg som är bättre utformat för att kunna taga hänsyn till olika former för offentlig religion som är finna på lokalt, nationellt och transnationellt nivå $i$ de senmoderna konsumtionssamhällena.

KEYWORDs: Secularisation, social differentiation, public religion, privatization, religion, churches, secularism.

Under lång tid har sekulariseringsteorins inflytande kraftigt påverkat vår syn på religion i det offentliga livet. Framförallt har föreställningen om att sekularisering både handlar om social differentiering och religionens privatisering varit inflytelserik. Tanken bakom detta är att moderna samhällen karaktäriseras av en ökande specialisering och en åtskiljning av olika sociala funktioner. Som följd av denna process utvecklar skilda sociala institutioner en allt större autonomi och ett oberoende, samtidigt som religionen förlorar många av sina tidigare roller - inom lagstiftning, utbildning, välfärd och så vidare - och reduceras till något rent privat utan vidare socialt eller politiskt inflytande.

Idén om privatisering har kommit under stark press de senare år då religionens offentliga betydelse blivit mer och mer synlig; men den underliggande synen på differentiering och privatisering tenderar att förbli intakt. För José Casanova, vars arbete diskuteras senare, är både social differentiering och religionens privatisering en realitet, men det har för nyligen skett en "avprivatisering" genom vilken religionen har expanderat bortom den privata sfären och in i en annan - differentierad - sfär, civilsamhället. Samtidigt frågar sig en stor del av den nyare akademiska och politiska diskursen huruvida och på vilka villkor det kan vara legitimt att religionen har en plats i det offentliga livet. Denna fråga ställs under antagandet om att religionen har lämnat det offentliga livet, och att de olika offentliga arenorna faktisk har en möjlighet at välja om de vill tillåta (på sina egna villkor) att religionen återinträder.

Denna artikel ställer kritiska frågor om dessa inflytelsrika ideer och sättet på vilket de fortsätter att ha ett inflytande på hur man ser på 'offentlig religion'. Medan användbarheten av begreppet social differentiering accepteras när det talas om moderna samhällens struktur, argumenteras det både för att det inte finns någon nödvändig länk mellan social differentiering och privatisering av religion och att framställningar av social differentiering inte bör överdriva åtskillnaden och autonomin hos olika sociala sfärer, inklusive religionen. Frågan om "offentlig" religion bör vara mer öppen för empirisk undersökning. För närvarande omöjliggör de existerande modellerna för offentlig religion sådana undersökningar genom att anta att religion endast kan hittas i den privata sfären eller i civilsamhället. Denna artikels huvudsakliga bidrag är att erbjuda en ny modell för offentlig religon vilken öppnar för empiriska - och historiska 
undersökningar - genom att ge förslag till var offentlig religion kan finnas, och hur dess placering, makt och sårbarhet kan bli kartlagd tvärsöver skilda sociala domäner.

\section{Två dominerande modeller för offentlig religion}

Min utgångspunkt är att det finns två dominerande modeller för offentlig religion i den akademiska, men också i den bredare, diskursen (inkluderande flera politiska, juridiska och journalistiska diskurser). De är båda bundna till var sin samhällsmässiga historiska bakgrund. Den första är tätt bunden til europeiska förhållanden och den andra till amerikanska (framförallt USA).

\section{Två-domän modellen (offentligt/privat)}

Två-domän modellen skiljer skarpt mellan "offentlig" och "privat" sfär. Med hänsyn til religion är den upptagen av att placera denna i en av dessa sfärer (den är generellt ovillig att se möjligheten att religion kan finnas i bägge). Till övervägande del, som i Bryan Wilsons betydelsefulla arbete från 1970-talet och fram till 1990-talet, argumenterar den för at religion i moderna samhällen inte längre har sin plats i den offentliga sfären utan i den privata. Denna syn är bundet upp på en teori om social differentiering och privatisering: när samhällen moderniseras, blir religionens olika offentliga roller - inom juridik, politik, utbildning etc - mindre betydelsefulla genom att dessa sfärer i ökande grad blir differentierade från varandra och självstyrande (och/eller statligt styrda). Denna syn representeras i dag av forskare som Steve Bruce (ex. Bruce 1996).

Det är värt att notera tre kännetecken för modellen

(a) Den är förbunden med (teleologiska) moderniseringsteorier (och med sekulariseringsteorier som är knutna till dessa), då den ser på religion i moderniteten som att den oundvikligt flyttar sig från den offentliga domänen till den privata, och att dess synlighed minskas under vägen.

(b) Den glider lätt mellan det deskriptiva och det normativa, i en sociologisk gestalt presenterar den sig som det förra, men i politiska och andra diskurser framstår det klart hur svårt det är att i praktiken vidmakthålla gränsen. Handlar det om att religion är en privatsak, eller handler det om att religion borde vara en privatsak? Ser "sekulära" nationalstater och deras representanter situationen som den är eller hur de menar att det borde vara? Som många filosofer, historiker och feminister har argumenterat för finns det en stark lukt av ideologi omkring hela idén om distinktionen offentlig/privat - och ännu mera omkring religionens "privatisering".

(c) I den mån som den erkänner religionens offentliga roll - även om detta betraktas som något förflutet - ger den företräde för en relation mellan religion 
och politik där det senare förstås i termer av handlingar utförda av nationalstaten, dess politiker och politiska partier.

Jag menar att denna model i grunden är europeisk. Framförallt likställer den religion med kyrkor. Kyrkor - som något annat än församlingar och denominationer - är något unikt europeiskt. I den form vi fortfarande kan hitta dem är deras historia i grunden byggt på nationalstatens. I själva verket är de europeiska staterna och kyrkorna homologa av den enkla anledning att de utvecklades tillsammans (detta är mest tydligt för de protestantiska kyrkorna, men det gäller också till stor del de "nationella" katolska kyrkorna som kom efter motreformationen). Vad två-domän-modellen fokuserar på är inte en universell process för "religionens privatisering" utan en mycket historisk specifik process genom vilken moderna stater försökte att få lösare band till kyrkorna och samtidigt få större kontroll över dem (Woodhead 2004).

\section{Tre-domän modellen (offentligt/civilsamhälle/privat)}

“Två-domän" modellen konkurrerar med en "tre-domän" modell. Denna blev populariserad och utvecklad af José Casanova (1994). Till skillnad från två-domän modellen, vilken har sin utgångspunkt i den europeiska kontexten, har tre-domän modellen sin i en amerikansk kontekst. Dess förelöpare finns i arbeten av de Tocqueville, Talcott Parsons, och Robert Bellah. Alla dessa tog det avgörande steget att inte primärt lokalisera religion i det "offentliga" (i betydelen av statligt agerande) men inte heller i det "privata" livet (fastän religionens närvaro där accepterades) utan i sfären för det "civila" livet. Casanova utvecklar denna modell. Han blandar den med två-domän modellen genom att acceptera den senares påstående om att religionen blivit privatiserad genom den sociala differentieringen, men argumenterar för att den nu är på väg att bli "avprivatiserad". Resultatet är att religion över hela världen inte längre primärt eller utslutande är lokaliserad i den offentliga eller i den privata domänen, utan att den också finns i en mellanliggande domän, "civilsamhället".

Medan två-domän modellen i grunden är europeisk, menar jag att denna modell i grunden är amerikansk (US American). Dess koppling till den konstitutionellt garanterade åtskillnaden mellan kyrka och stat, som är unikt för USA, är mycket klar. I likhet med den europeiska modellen, är den nära knuten til en ideologi, men i detta fall är ideologin inte fokuserad på en "ideel" kyrka/stat-åtskillnad som betraktas som förutsättning för politisk frihet och statlig autonomi, utan en "ideel" kyrka/stat-åtskillnad som betraktas som förutsättningen för religiös frihet, medborgerlig autonomi och en vital civil sfär som står fri från statlig inblandning. Medan det post-koloniala moderna Europa lämnade efter sig en modell med progressiva, socialistiska och sekulära stater som agerade med sina borgares intressen för ögonen och som ignorerade religionen vilket betraktades som en privat sak, föredrog det "neo-koloniala" USA att uppmuntra en dynamisk och levande civil sfär och en marknadssfär som stod fria från statlig in- 
blandning och där religiös frihet sågs som det avgörande testet på att man lyckats. Två-domän och tre-domän modellerna för offentlig religion har ett nära samband med dessa program. Som sådana har de haft ett inflytande som sträcker sig långt utanför Europa.

\section{Problem med dessa modeller}

Dessa två "klassiska" modeller för offentlig religion står nu inför allvarliga problem. Det allvarligaste är inte att de är bundna till en bestämd plats och tid, eller deras förbindelser med ideologier - eftersom ingen modell, hur universell den än hävdar att den är, i verkligheten kan överskrida sina egna förutsättningar (även om den kan vara mer eller mindre självkritisk i förhållande till dessa). En mer allvarlig invändning som modellerna nu står inför är att de inte kan ta tillräcklig hänsyn till att de religiösa landskapen under de senaste decennierna snabbt har förändrats. Detta är lika sant med hänsyn både till det europeiska och det amerikanska och då har vi inte beaktat förhållandena i resten av världen.

\section{i. Det religiösa landskapet har förändrats}

Ett skäl till att de inte längre fungerar är att religionen själv har förändrats så dramatiskt i Europa sedan 1970-talet. Den mest uppenbara förändringen i Västeuropa är att det kristna monopolet har fallit, vilket innefattar (a) en dramatisk nedgång för de historiska kyrkorna (ex. kyrkor med reformatoriskt eller för-reformatoriskt ursprung, framförallt protestantiska och katolska) och (b) en förlust av kulturellt monopol och därmed också en nedgång för prästerskapets status. Den allvarligaste nedgången av alla har de protestantiska kyrkorna upplevt, i själva verket handlar det om alla kyrkor som har varit nära knutna till nationalstaten. Gudstjänstbesök, medlemsskap och andra relevanta statistiker för kyrkor som Church of England eller Svenska kyrkan har mer än halverats sedan 1970-talet (i många länder har den katolska kyrkan upplevt detsamma även om nedgången började senare) ${ }^{2}$. Det minskade kulturella inflytandet har sin grund i en mängd faktorer, mest anmärkningsvärt är den kraftiga tillväxten av de "kulturella klasserna" från 1960-talet (i media, utbildning, humanistiska områden), vilket i hög grad har minskat prästerskapets kulturella makt och ofta har resulterat $i$ ett frontalangrepp mot dess auktoritet. Den moraliska auktoriteten har också blivit undermine-

2 Gudstjänstbesök i England

\begin{tabular}{|l|l|l|l|l|}
\hline$\AA r$ & 1979 & 1989 & 1998 & 2005 \\
\hline Deltagande i procent & 11,7 procent & 9,9 procent & 7,5 procent & 6,3 procent \\
\hline
\end{tabular}

Källa: Brierley (2006: 12.2.1). 
rad, mest dramatiskt för den romersk-katolska kyrkan genom de återkommande skandalerna omkring övergrepp på barn och kyrkans hantering av detta.

Tillbakagången för de historiska kyrkorna är inte synonymt med en generell kristen tillbakagång. Snarare har det skett en massiv omgruppering inom kristendomen. Kristendomen, om man ser till världen som helhet, har vuxit kraftigt sedan 1970-talet, men då huvudsakligen i dess karismatiska/pentakostala former (Barret 2001). I Europa har det trots en generell nedgång också varit en liknande omgruppering 3 . Mest slående i relation till debatten om offentlig religion är att kyrkor som hade etablerat nära allianser med stater (och lokalsamhällen) har blivit tvingade att kämpa, medan de som stått oberoende i förhållande till staten, men nära lierade med marknaden, familjen och konsumtionskapitalismen, har blomstrat. Samtidigt har det religiösa landskapet ändrats genom två andra faktorer.

En är den fortsatta tillväxten av "alternativa" och "holistiska" former av spiritualitet. Trots att de har sitt ursprung i självmedvetna alternativ till den kristna tron från mitten av 1800-talet, har denna spiritualitet, på grund av många olika orsaker, blomstrat från det sena 1980-talet, och har varit särskilt framgångsrikt förankrat inom vissa bestämda områden av det offentliga livet, däribland hälsovården (se nedan). Detta är framförallt kvinnornas domän (upp emot 80 procent - Heelas och Woodhead 2005) och den tar organisatorisk form på tre nivåer: (i) lokalt, små grupper och en-till-en terapier (understött av en explosion av böcker och internet-material) (ii) regionala utbildningar och workshops (iii) nationella och internationalla möten, mässor och festivaler. Detta område har nu utvidgats till att innefatta olika former för ny-hedendom (inklusive Wicca och eko-spirituella rörelser), new age och en mängd "kropp-själ-ande"tekniker (Yoga, Reiki etc.). Sointus och Woodheads (2008) studie av undersökningar utförda i Europa och Nordamerika visar att antalet aktiva, mycket engagerade och regelbundna deltagare är omkring 2-5\% av befolkningen; andelen av befolkningen som är anhängare (dvs. andelen som hävdar att de är "spirituella men inte religiösa") ligger omkring 10-20 \%; och andelen som har karaktäristiska trosföreställningar, (såsom en tro på "någon form för ande eller livskraft" eller en tro på "Gud som något inom varje människa snarare än något utanför") ligger någonstans mellan 20 och $40 \%$. Generellt är nivån högre i USA och Nordeuropa än i Sydeuropa (man skall dock vara klar över att detta inte på något sätt är ett exklusivt västligt fenomen med det saknas däremot data från andra delar av världen) ${ }^{4}$. Den holistiska spiritualitetens inflytande inom kulturen i stort är nu omfattande, fler människor i Storbritannien (2010) tror nu på Gud som "ande eller livskraft" (44 procent) än på en "personlig gud" 26 procent)

3 I Storbritannien har t.ex. den anglikanska och den romersk-katolska kyrkan sett sina "marknadsandelar" minska, medan en rad baptistiska, oberoende, karismatiska kyrkor har växt. Sålunda var år $200528 \%$ av kyrkobesökarna anglikaner, $28 \%$ romersk-katolska och $44 \%$ tillhörde en rad mindre, voluntaristiska kyrkor, däribland baptistiska, oberoende och karismatiska kyrkor (Brierley 2006: 12.2.2).

4 De olika källorna till dessa data finns listade i Sointu and Woodhead (2008). 
och begrepp som "chi", "chakra", "zen" är nu vanligare än till exempel "treenighet", "uppståndelse" eller "sakramental"

Den andra stora förändringen av det religiösa landskapet i västvärlden sedan 1980-talet har varit det växande antalet ikke-kristna "världsreligioner" som också fått offentlig synlighet och inflytande. Detta är ett resultat av immigration och har vidmakthållits av transnationella band likaväl som av nya institutioner och en förankring på nationell nivå Den numeriskt mest betydelsefulla och politiskt stridslystna är Islam, men också Hinduism, Sikhism och andra religioner är betydelsefulla.

Fastän både det offentliga och det privata inflytandet inom majoritetsbefolkningarna inte har varit så stort som den alternativa spiritualitetens (vilken i sig har anknytning till buddhism, hinduism, sufi-islam) så har islams politiska och mediala profil varit mycket tydligare, inte minst på grund av våldshandlingar och terrorism men också på grund av hur Islam har blivit framställd i västliga staters både inrikes- och utrikespolitik. förbindelser till en vidare politisk agenda inkluderande den amerikanska neokonservatismen. Dessutom, har alla dessa religiösa samfund, med undantag av några varianter av buddhism, i högre grad än den alternativa spiritualiteten ställt politiska och ibland juridiska krav på stater och någon gång på EU-nivå. Detta har delvis sin grund i det faktum att de har - eller har blivit uppmuntrade att utveckla - några

5 Tro på en personlig gud

Storbritannien, alla vuxna, procent

\begin{tabular}{|c|c|c|c|c|c|c|}
\hline & \multicolumn{6}{|c|}{$\begin{array}{l}\text { Tror du på en personlig Gud, Gud som en universell ande eller livskraft, } \\
\text { eller att det inte finns någon Gud? }\end{array}$} \\
\hline & Agency & $\begin{array}{l}\text { Personlig } \\
\text { Gud - alla }\end{array}$ & $\begin{array}{l}\text { Ande/livs- } \\
\text { kraft }\end{array}$ & Osäker & Ingen Gud & $\begin{array}{l}\text { Vet inte/ } \\
\text { NA }\end{array}$ \\
\hline 1947, December & Gallup & 45 & 39 & 16 & & \\
\hline 1957, February & Gallup & 41 & 37 & 16 & 6 & \\
\hline 1961, September & NOP & 57 & 22 & 12 & 7 & 3 \\
\hline 1963, March-April & Gallup & 38 & 33 & 20 & 9 & \\
\hline $\begin{array}{l}\text { 1963, December-1964, } \\
\text { January (England) }\end{array}$ & Gallup & 43 & 43 & 12 & 4 & \\
\hline $\begin{array}{l}\text { 1968, January- } \\
\text { February }\end{array}$ & ORC & 37 & 42 & 11 & 9 & \\
\hline 1970, June & NOP & 40 & 37 & 11 & 7 & 5 \\
\hline 1974, August & Harris & 29 & 35 & 18 & 6 & 12 \\
\hline 1979, March & Gallup & 35 & 41 & 17 & 8 & \\
\hline 1981, March & Gallup & 30 & 39 & 19 & 9 & 4 \\
\hline 1981, April & Gallup & 36 & 37 & 14 & 12 & \\
\hline 1984, March-April & Harris & 40 & 33 & 12 & 11 & 4 \\
\hline 1986, July & Gallup & 31 & 41 & 11 & 16 & 0 \\
\hline 1989, December & Gallup & 30 & 39 & 19 & 12 & 1 \\
\hline 1990, June-September & Gallup & 32 & 41 & 15 & 10 & 1 \\
\hline 1993, May & Gallup & 30 & 40 & 15 & 14 & 1 \\
\hline $\begin{array}{l}\text { 1999, October- } \\
\text { November }\end{array}$ & $\begin{array}{l}\text { Quality } \\
\text { Fieldwork }\end{array}$ & 28 & 37 & 17 & 9 & 9 \\
\hline 1999, November? & $\begin{array}{l}\text { TNS } \\
\text { TNelawork }\end{array}$ & 25 & 43 & 15 & 16 & 1 \\
\hline 1999, December & ORB & 28 & 37 & 16 & 17 & 3 \\
\hline 2000, April-May & ORB & 26 & 44 & 12 & 15 & 3 \\
\hline
\end{tabular}

Källa: http:/ /www.brin.ac.uk/figures/\#ChangingBelief (sedd 11-9-2011) 
strukturella likheter med kyrkorna och den därav tillsvarande förmågan att organisera sig på ett sätt som gör det möjligt för dem att förhandla med nationella, regionala och lokala regeringsorgan och att försäkra sig om politisk representation (medan alternativ spiritualitet föredrar att deltaga i direkta former för mobilisering och politisk handling och tenderar att undvika "indirekt" eller "gammal" politik; den vill hellre agera på ad hoc basis).

Slutligen är det viktigt att betona att de flesta människor varken är "religiösa" eller "sekulära". Endast en minoritet, också i de mest sekulära länder i världen, ser sig som ateister, men samtidigt är det också enbart en minoritet som tillsluter sig trosföreställningarna hos en enda religiös "ortodoxi". Det är alltför förenklat att ge den återstående majoriteten av befolkningen etiketten "otydlig" eller "förvirrad". I verkligheten blandar de flesta människor element av både "religiösa" och "sekulära" förpliktigelser i de egna reflexiva livshållningarna (t.ex. engagement i både Islam och kamp för mänskliga rättigheter; engagement i Islam och praktiserande av Reiki; att man identifierar sig som kristen och samtidigt tar avstånd från grundläggende dogmer i kyrkan). Det har förmodligen alltid varit så att de flesta människors bruk av religion har varit mer taktisk än strategisk - man är intresserad av "det som fungerar" i det verkliga livet och inte av att hålla hårt på tydliga gränser mellan tro, akademisk teori eller institutionell tillhörighet. Det är uppenbart varför det är svårt att lagstifta om sådan "religion", men det är fortfarande viktigt att komma ihåg att detta är normen snarare än undantaget.

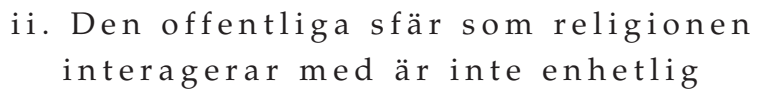

Varken två-domän modellen eller ens tre-domän modellen ger en rättvisande bild av hur spridd och divers den religion, som är involverad i den offentliga sfären, idag är. Två-domän modellen är mest bristfällig och har nu blivit vitt kritiserad för sin oförmåga att se eller förklara fortsatta - och nya - offentliga uttryck för religon. Avprivatiseringsteorier representerar en viktig reaktion, trots att de alltför lätt förutsätter att religion faktiskt privatiserades på ett tidspunkt i historien. Än viktigare är att de förutsätter att religionen fortsätter att vara tätt bundet till, och begränsad av, en differentieringsprocess som ger den ett snävt handlingsutrymme. I Casanovas teori, och de många varianter som den har inspirerat till, är detta "civilsamhällets" sfär - men vad är "civilsamhälle" och är religion verkligen begränsad till detta? Det finns två tolkningstraditioner med avseende på civilsamhälle. Casanova tenderar att följa den amerikanska som stammar från de Tocqueville (och i sista hand Jean Jacques Rousseau) som ser civilsamhälle som en moralisk ("civil") domän för dygd och aktivt medborgarskap som ligger mellan staten och familjen/privatlivet och som är något grundläggande för vitalitet och sundhet i ett samhälle. Enligt denna tradition är civilsamhället i allt väsentligt nationell, även om det i senare tid gjorts försök på att tala om ett "globalt civilsamhälle". Den andra tolkningstraditionen är mer europeisk och betraktar, enligt Gramsci, ci- 
vilsamhället mindre som en domän för sammanhållning och mera som en domän i vilken det förs en kamp mellan konkurrerande sociala och kulturella rörelser och projekt (Gramsci 1971, Walby 2009). De mest framgångsrika av dessa har blivit institutionaliserade i politiska och juridiska strukturer; civilsamhället är således motorn som driver social förändring.

Det är mycket att vinna genom att se på religion i relation till civilsamhälle, framförallt civilsamhälle förstått i termer av Gramsci-traditionen, och som något som flyter över nationella gränser. Jag är mer skeptisk till den amerikanska traditionen, med dess tendens till att göra religion till en del av medborgerlig dygd och (i Putnams och andras arbete) till en källa för "socialt kapital" - detta blir lätt idealiserande och överdrivet programmatiskt. Det finns emellertid också goda teoretiska och empiriska skäl för att inte binda vårt tänkande omkring offentlig religion enbart till idén om civilsamhälle. Trots att tre-domän modellen går längre än två-domän modellen, är den fortfarande överdrivet begränsad när man betraktar den komplexa verkligheten i västvärlden som offentlig religion befinner sig i, för att inte tala om den övriga världen. Till och med i USA, vars konstitution strävar efter att hålla religionen utanför den statliga domänen och i den civila, är situationen inte helt klar. I andra länder, med sina mycket olika konstitutioner, är gränserna mellan "domänerna" ännu mera oklara. I många europeiska länder finns till exempel viktiga rester av den historiska relationen mellan religion och stat kvar, även om banden formellt blivit upplösta - detta gäller inte minst sfärerne för hälsa, utbildning och välfärd. I praktiken är detta också sant för ett land som Frankrike, trots dess program för laïcité, och för USA, trots dess konstitutionella garantier (om också utbildning av historiska orsaker är det område i vilket åtskillnaden är tydligast säkrad).

Ett sätt att formulera detta är att säga att gränserna mellan både stat och civilsamhälle och mellan civilsamhälle och privatliv, är långt mera oklara och porösa än vad tre-domän modellen antar: statens inflytande sträcker sig ner både i civilsamhället och i det "privata" livet, på samma sätt som det "privata" livet och civilsamhället konstant blandas in i statliga angelägenheter och statliga förordningar (om exempelvis giftermål och familjeangelägenheter). Men ett bättre sätt att uttrycka det på är att säga att tredomän modellen behöver utvidgas kraftigt för att den bättre skall kunna fånga det sociala livets diversitet och religionens plats härinom. På många sätt skakar den utvidgningen själva grundvalen för modellen, då det fort blir tydligt att många sociala domäner inte enkelt kan kategoriseras som att höra till en av de tre "domänerna" häribland utbildning i de flesta europeiska länder, och hälsovård och välfärd i nästan alla länder. Nödvändigheten för att udvidga modellen har enbart förstärkts genom nationalstaternas minskande makt relativt marknadens, då både två-domän och tredomän modellerna identifierar det "offentliga" med nationalstaten och statliga aktörer på ett sätt som nu i hög grad är diskutabelt.

När man skall försöke at förstå offentliga uttryck för religion idag, är ett alternativt tilvägagångssätt att arbeta med en bredare modell för samhällets olika områden i vilka religion är involverad. Här kan idén om social differentiering komma till vår hjälp, så 
länge man kommer ihåg att, fastän de är differentierade från varandra i några hänseenden, är gränserna mellan de olika sfärerna i själva verket skiftande och oklara. Dessutom finns det många sätt på vilka de olika domänerna kan bli "tillyxade", och olika samhällen kan kräva något olika modeller. I relation till Storbritannien skulle jag inkludera de domäner som visas i Fig 1. Det finns inte någon logik i sättet på vilket jag har framställt deras relativa position, och en annan, lämpligare, illustration kan möjligen visa på deras ömsesidiga relationer och överlappningar på ett sätt som jag inte har prövat. Detta representerar tydligt en betydande utvidgning bortom både tvådomän och tre-domän modellerna för offentlig religion, men jag menar att den öppnar för mera nyanserade och precisa analyser.

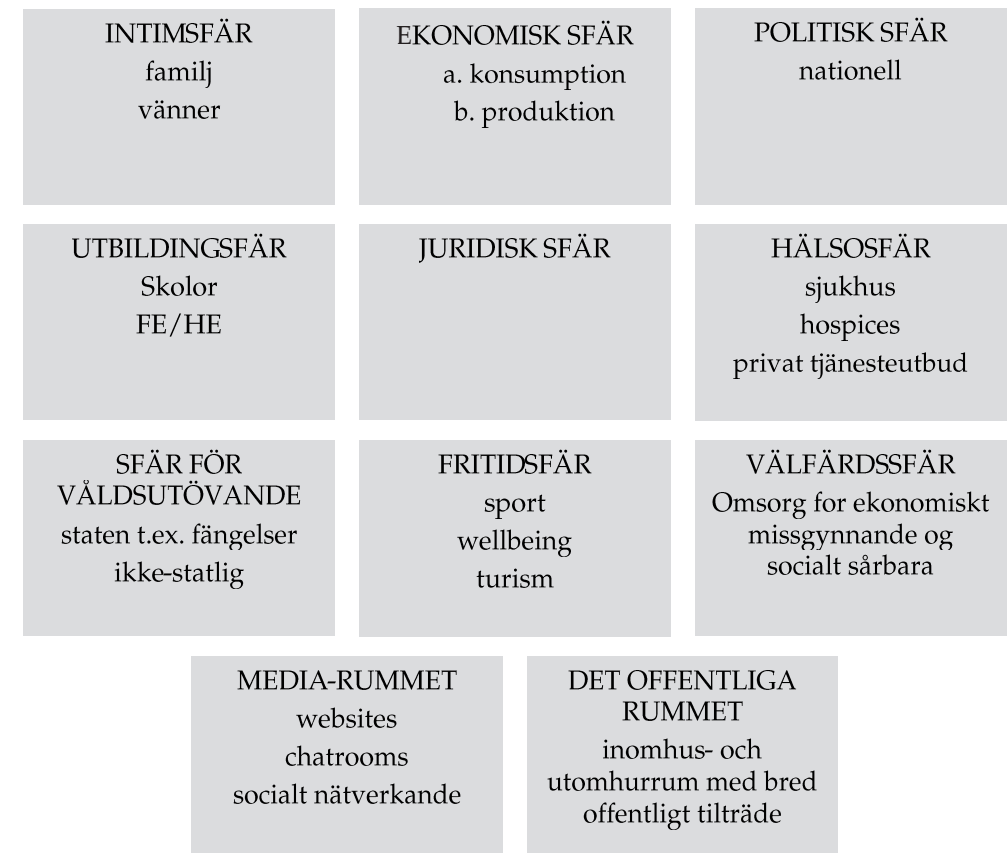

Fig. 1. Domäner för offentlig religion (Storbritannien)

iii. Olika typer av sekularism som en komplicerande factor

De existerande domän-modellerna tar som utgångspunkt att den "offentliga sfären", framförallt staten, inte längre är en domän för religion, och att en "sekulariseringsprocess" - definierad i termer av differentiering och privatisering - har fört till att religionens inflytande har minskat (drastiskt för två-domän modellen, mindre drastiskt för tre-domän modellen). Denna syn undervärderar den utsträckning i vilken sekularisering inte är en passiv effekt av moderniseringsprocessen, utan istället en aktiv politisk kamp mellan olika grupper, intressen och ideologier. Den ignorerar också sekularismens 
historiska och geografiska variationer, och i vilken grad det sekulära definieras av de former för religion som de konkurrerar med om herradömet över olika sfärer (det sekulära i USA är till exempel mycket olik laicite i Frankrike, sekularism i Indien är mycket olika den i Kina). Den struntar också i att ta hänsyn till att sekularism kan vara mycket olika inom olika sfärer - från en politiskt ateistisk socialism i den politiska sfären till, som exempel, till nyliberal "yttrandfrihets"-sekularism inom media, konst och kultur, socialvetenskapliga och "professionella" sekularismvarianter inom utbildning (särskilt inom högre utbildning). Som Taylor (2007) visar är det sekulära inte ett "naturligt" fundament som finns kvar när det religiösa tidvattnet ebbat ut, utan en konkurrerande meningssystem och där till hörande institutioner. De olika domänerna beskrivna här ovan behöver analyseras i termer av konkurrerande sekulära och religiösa krafter och deras förändrade maktkonfigurationer och maktbalanser över tid. Detta är ett sätt på vilket den offentliga religionens maktdimension - det politiska med ett litet " $\mathrm{p}$ " - kan ges en större synlighet.

\section{Ett nytt sätt att utforma en modell för offentlig religion}

Dessa reflektioner tvingar oss i riktning mot ett nytt tillvägagångssätt i utformningen av en modell för offentlig religion, som tar större hänsyn till de många domäner inom vilka religion är aktiv i dagens samhällen, och som tillåter oss att jämföra dem i den mån som nationalstaten fortfarande finns kvar som en användbar bas för analys och jämförelse (vilket borde stå som en öppen fråga). Den nya modellen kan också användas för att analysera lokala, regionala och övernationella former för offentlig religion när detta är ändamålsenligt.

Utgångspunkten är den mer komplexa model för den offentliga religionens sfärer som visas i FIG.1. Denna är en mer användbar grund för analys än två- och tre-domän modellerna och kan också modifieras så att den passar skilda nationella kontexter.

Nästa moment i modellbyggandet är beskrivningen av de varianter av religion som är mest framträdande i varje domän. Detta är en empirisk fråga. Det kan inte längre antas att offentlig religion är det samma som någon form för kristendom: de specifika formerna (ibland konkurrerande) av kristendom är av intresse, men analysen skall också vara öppen för förekomsten av andra former för "världsreligion" eller av holistisk spiritualitet eller av olika blandformer. I många fall kommer alla att vara där samtidigt, och det är viktigt att begrunda deras relativa styrkor och svagheter, så väl som deras relationer till varandra. Det senare kan bestå av samarbete (som i några former för sjukhus- eller fängelseprästerskap); det kan också vara fråga om ren konkurrens mellan dem (som i konkurrensen att få driva statligt finansierade sociala välfärdsinstitutioner) - och så vidare.

Om man går till väga på detta sätt är det möjligt att modifiera FIG.1 i syfte att visa på de olika religionstyperna som är aktiva inom varje domän. Då detta endast är möjligt genom färg-kodning (och då denna artikel kommer att tryckas i svartvitt), kommer 
jag att inskränka mig till att indikera med ord vad detta kan föra med sig. Två sfärer kommer att fungera som illustration, och jag kommer att fortsätta att använda Storbritannien som eksempel.

a. Hälsa. Om vi tittar på de två viktigaste aspekterna av denna domän, nämligen (a) det statligt reglerade och delvis statligt finansierade biomedicinska hälsosystemet och (b) alternativa former för privat utbud av "komplementära och alternativa" former för hälsovård och helande, står det klart att kristendom - framförallt statskyrkan - är den dominerande formen för religion i den förra, och holisitiska former för kropp-själande spiritualitet i den senare (komplementär och alternativ hälsovård används nu av omkring $40 \%$ av den vuxna befolkningen). De 2-3 senaste decennierna har vi sett betydande förändringar - för det första i tillväxten av ett alternativt spirituellt utbud, men också hur detta i stigande grad har integrerats i det "statliga" utbudet, mest dramatiskt i relation till mental hälsa, smärtkontroll, palliativ vård och inom vårdutbildning; och för det andra sättet på vilket präst-team har utökats så att de nu innehåller präster med olika trosuppfattningar, däribland muslimska, hinduistiska och andra.

b. Välfärd. Skapandet av välfärdsstaten i Storbritannien innebar att staten övertog och rationaliserade några av kyrkornas filantropiska aktiviteter och institutioner för välfärd, särskilt gäller detta statskyrkan vilken aktivt samarbetade med välfärdsprojektet. Denna process blev påskyndad genom rekommendationer från socialvetenskapen och socialpolitiken, och genom "professionaliseringen" av aktiviteter som "socialarbete" (vilket ofta var kombinerat med en socialistisk eller marxistisk ateistisk tendens från det sena 1960-talet till det tidiga 1980-talet). Trots detta fortsatte religioner av olika slag att utbjuda parallella tjänster, inte minst gäller detta de växande immigrantreligionerna, då i förhållande till den egna befolkningsgruppen. Dessutom har några former för utbud fortsatt att levereras av kyrkorna, däribland hjälp till hemlösa, varav omkring hälften fortfarande tillhandahålls av "radikala" protestantiska grupper som Frälsningsarmén. Från 1980-talet och framåt har staten, med ideologiskt stöd av nyliberalismen, i ökande grad räknat med att "trosbaserade organisationer" skulle leverera ett ökande utbud av välfärdstjänster, och då i konkurrens med andra religiösa och icke-religiösa NGO-er inom "frivilligsektorn". En effekt av detta är att organisationer som Frälsningsarmén har vuxit samtidigt som de har utvecklat sin expertis och sina byråkratiska resurser för att kunna ge konkurrenskraftiga bud på regeringskontrakt.

Om man sålunda skulle försöka visa religionens alla varianter på diagrammet ovan skulle färgkodningen visa den offentliga närvaron av (historiska) kristna kyrkor och holistisk spiritualitet inom hälsoområdet, och "radikala" protestantiska kyrkor plus en rad nya trosbaserade tjänsteutbjudare (särskilt kristna och islamiska) inom välfärdsområdet.

En sak som dessa exempel indikerar är inte bara den ökande mångfalden inom det religiösa landskapet, utan också marknadens såväl som statens ökande inflytande både på staten själv (som i strävandena att bjuda på kontrakt i en "blandad ekonomi" för välfärd) och i erbjudande av nya möjligheter för religion och till en mycket bredare uppsättning av religiösa aktörer (som i tillväxten av kropp-själ-ande praktiker som är 
oberoende av statens agerande, både i förhållande till finansiering och reglering). Många sådana spiritualiteter, likaväl som religiösa NGO-er som Frälsningsarmen är nu transnationalla snarare än nationella.

Nästa steg är att modellen måste ta hänsyn till samspelet mellan det sekulära - och varianter på sekularism/sekularitet - och det religiösa i varje domän och till hur deras relationer ser ut. Detta betyder att man skall överväga hur sekulära grupper, institutioner och intressen interagerar med religiösa. I likhet med de andra aspekterna förändrar sig detta över tid. Situationen är klart en annan i länder med en mer aggressiv sekulariserande politik (som i Östeuropa) än i andra.

Till exempel i förhållande till exemplet med hälsa som just diskuterats föreligger en klar trend genom hela det 20e århundradet att den sekulära staten samordnar och "övertar" ett religiöst utbud av tjänster (t.ex. sjukhus drivna av kyrkan och frivilliga sjukbesökare) och skapar ett mer generellt och samordnat hälsovårdssystem. Nyckelgrupper som stödde detta är "vetenskapliga" medicinskt professionella, huvudsaklingen män, som ofta tar andra aktörers plats. En ytterligare sekulär kraft är den växande "professionalliseringen" och utbildningen, som ofta tar avstånd från religiösa förhållningssätt till hälsa och helande. Dessa krafter fortsätter att konkurrera med religiösa och spirituella former för tillhandahållande av dessa tjänster, fast under senare tid finns det tecken på större samarbete inom ett antal områden.

I det hela taget är det nyttigt att reflektera över det religiösas och det sekuläras relativa makt inom varje område. Är varje sfär huvudsakligen sekulär, enbart med en liten rest av religion kvar (som privatiseringsteorierna förutser) eller spelar religion en viktigare roll? Är det möjligt att på diagrammet i FIG. 1 visa, genom att använda olika färger, eller olika gråa schatteringar, var det religiösa har mest makt och inflytande. Fig.2 är ett försök på att visa hur detta skulle se ut i dagens Storbritannien. 

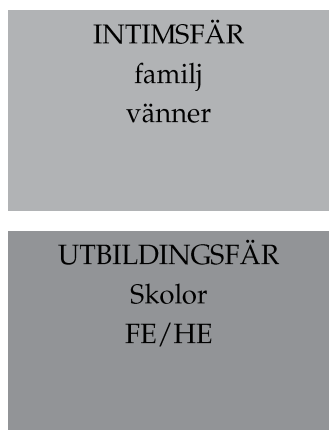

SFÄR FÖR

VÅLDSUTÖVANDE

staten t.ex. fängelser ikke-statlig

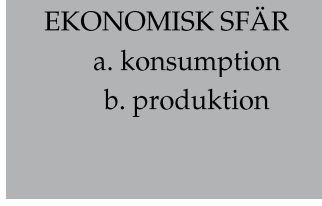

JURIDISK SFÄR
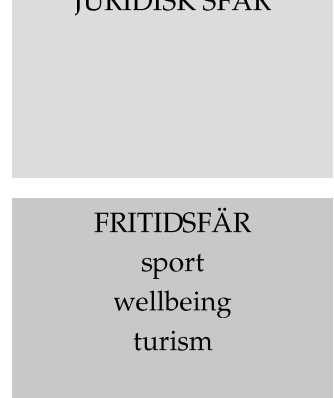

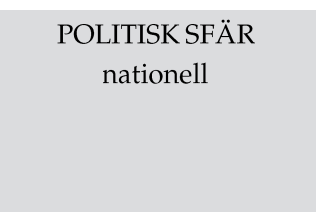

HÄLSOSFÄR

sjukhus

hospices

privat tjänesteutbud

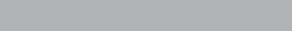

VÄLFÄRDSSFÄR

Omsorg for ekonomiskt missgynnande og socialt sårbara
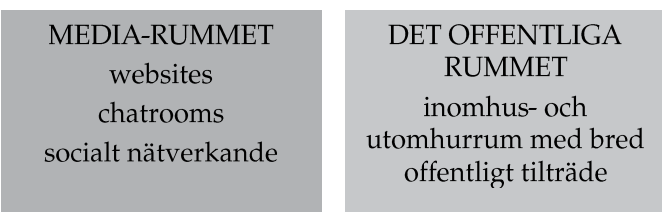

Fig. 2. Religionens makt i olika sfärer, Storbritannien (spekulativt), (mörkast $=$ mest makt)

Slutligen är det nödvändigt att komplicera bilden ytterligare genom att ta i beaktande den interna differentieringen inom varje område, och det sätt på vilket det finns en motsvarande tillpassning av religionens roll. Som vi till exempel har sett med hänsyn till hälsovård är religionens makt i det alternativa utbudet extremt hög, medan i det offentliga, biomedicinska hälsovårdssystemet är det fortfarande generellt lågt, men det finns dock koncentrerat i ett fåtal "fickor" (som mentalsjukvård).

Det finns också med stor sannolikhet en mycket klar differentiering, med sin grund i klass, kön, etnicitet och andra sociala variabler, som behöver utforskas. Sådana differentieringar löper ofta längs desamma bristfälliga linjer i religion och i olika sociala domäner. Sålunda är religion differentierat i termer av social makt: historiska kristna kyrkor - inklusive statskyrkor - har mycket större socialt anseende än nyare protestantiska sekter, alternativ spiritualitet och ikke-kristna religioner och har med större sannolikhet lojalitet och stöd från de högre klassers vita män. På motsvarande sätt är de olika domänerna inom offentlig religion också internt differentierade i termer av social makt - så har till exempel högre utbildning och dess professionella anställda större social makt än gymnasie- och folkskoleutbildning och motsvarande högre koncentration av högre klassers vita män. Då dessa två uppsättningar av social stratifiering har idenfierats, kan man söka efter korrelationer - eller anomalier - mellan dem. Till exempel kan vi i Storbritannien se att inom utbildningsområdet är religion (framförallt 
spiritualitet som har låg status och förbundet med kvinnor) mest inflytelserikt inom folkskoleutbildningen medan kyrkorna har mycket större inflytande inom gymnasieutbildningen och att sekularismen dominerar inom högre utbildning, men med rester av statkyrkoinflytande inom de äldsta och mest ansedda universiteten.

\section{Konklusion}

Denna artikel erbjuder en kort skiss över hur det är möjligt att utforma en modell för offentlig religion på ett sätt som är mer lyhört för komplexiteterna i dagens situation än de existerande modellerna. Dess huvudsakliga fokus har varit på offentlig religion i Västeuropa men det borde vara möjligt att applicera också på andra kontexter.

Historiskt sett är inte den offentliga sfären något "neutralt" eller "sekulärt" med vilken religion nu söker förbindelse. Den var "religiös" långt innan den var sekulär och långt innan distinktionen religiös-sekulär existerade i sin nuvarande betydelse. Också dagens mest sekulära institutioner präglas av sina religiösa ursprung (oavsett om de förnekas eller imiteras eller bådadera). Den senare halvdelen av 1900-talet har utmärkts av uppkomst och fall av sekulära utopiska nationella projekt med en socialistisk framtoning i både koloniala och postkoloniala inramningar. Konsekvenserna av detta för offentliga religioner av alla slag (muslimska, hinduistiska, kristna, holistiska, "vardagliga" blandningar etc.) var djupgående. Detta förde nämligen med sig att religionen från 1950-talet och fram till 1970-talet blev ställd i skuggan av sekulära ideologier och institutioner (inkl. välfärdsstaten) och tvingades bort från den offentliga medvetenheten, vilket resulterade i att kyrkorna och staten förlorade kontroll över det religiösa fält. Men en effekt av detta var också att andra religiösa aktörer kom in på fältet under det sena 1970-talet, vilket tillät nya ideer och praktiker att utvecklas, med nya former för offentlig betydelse och potential. Dessa blandar och slår sig samman med äldre former för offentlig religion vilka har mer att göra med nationalstatens era än eran för transnationalle marknadsrörelser, men som fortfarande attraherar en oproportionerligt stor uppmärksamhet från lagstiftare, journalister och politiska beslutsfattare. Vårt tänkande om och vårt förhållningssätt till offentlig religion måste snabbt förändras för att vi skall kunna förstå denna nya situation, och modellen som presenterats här är ett försök att göra just detta.

\section{LITTERATUR}

Barrett, David B., George T. Kurian \& Todd M. Johnson

2001 World Christian Encyclopedia, $2^{\text {nd }}$ edition, Oxford University Press, Oxford and New York.

Brierley, Peter, ed.

2006 UK Christian Handbook: Religious Trends 6, 2006/7, Pulling out of the Nosedive, Christian Research, London. 
Bruce, Steve

1996 Religion in the Modern World: From Cathedrals to Cults, Oxford University Press, Oxford.

Casanova, José

1994 Public Religions in the Modern World, University of Chicago Press, Chicago.

Gramsci, Antonio

1971 Selections from the Prison Notebooks of Antonio Gramsci, Lawrence and Wishart, London.

Heelas, Paul \& Linda Woodhead

2005 The Spiritual Revolution. Why Religion is Giving Way to Spirituality, Blackwell, Oxford, UK and Malden, USA.

Sointu, Eeva \& Linda Woodhead

2008 Holistic Spirituality, Gender, and Expressive Selfhood. Journal for the Scientific Study of Religion 47 (2), 259-276.

Taylor, Charles

2007 A Secular Age, Harvard University Press, Cambridge and London.

Walby, Sylvia

2009 Globalization and Inequalities: Complexity and Contested Modernities, Sage, London.

Woodhead, Linda

2004 An Introduction to Christianity, Cambridge University Press, Cambridge.

Linda Woodhead, professor, PhD

Lancaster University, UK

Adjungeret professor

Religionsvidenskab, Institut for Kultur og Samfund, Aarhus Universitet 